\title{
Index to Volume $25(2021)$
}

Aghajanian, Arthur, Review of Armenia: Art, Religion and Trade in the Middle Ages edited by Helen C. Evans. 528-534.

Azar, Michael G. Exegeting the Jews: The Early Reception of the Johannine 'Jews' (reviewed). See DeCock, Review of Exegeting the Jews.

Bauman, Whitney A., ed. Meaningful Flesh: Reflections on Religion and Nature for a Queer Planet (reviewed). See Murphy, "Christianity and Climate Change."

Beitler III, James E. Seasoned Speech: Rhetoric in the Life of the Church (reviewed). See Woodward, Review of Seasoned Speech.

Bidgoli, Mehrdad. "Ethics, Subjectivity, and Alterity in King Lear: On Cordelia's Defiance and Sacrifice." 385-420.

Brisman, Leslie. "Studying the Bible in the 'Post-Truth' Era." 173-186.

Bynum, Caroline Walker. Dissimilar Similitudes: Devotional Objects in Late Medieval Europe (reviewed). See Snow, Review of Dissimilar Similitudes.

Carrasco, Davíd, Stephanie Paulsell, and Mara Willard, eds. Toni Morrison: Goodness and the Literary Imagination (reviewed). See Daily, "Goodness, Exceptionalism, and Sense."

Carson, Jordan. American Exceptionalism as Religion: Postmodern Discontent (reviewed). See Daily, “Goodness, Exceptionalism, and Sense."

Charoenkitsuksun, Lynne. Review of The Book in the Cathedral: The Last Relic of Thomas Becket by Christopher de Hamel. 352-356.

Charoenkitsuksun, Lynne. Review of The Mystic Lamb: Admired and Stolen by Harry de Paepe and Jan van der Veken. 357-361.

Colombo, Gabriel Miller. “'Extra-Special Care': Wes Anderson's The Grand Budapest Hotel as Liturgy." 617-640.

Coonradt, Nicole. “'To Be or Not To Be?': Hamlet and Tyrannicide.” 243-262.

Coonradt, Nicole. Review of Artemisia Gentileschi and Feminism in Early Modern Europe by Mary D. Garrard. 344-348.

Corrigan, John Michael. "The American Art of Memory: Idealism and the Romantic Construction of Cognitive Interiority." 70-98.

Cording, Robert. Finding the World's Fullness: On Poetry, Metaphor and Mystery (reviewed). See del Toro García, Review of Finding the World's Fullness.

Cotti-Lowell, Alison Fanous. "Entering the Latin American Igbodu: Immersive Studies of Religion and Spirituality in the African Diaspora." $485^{-5}$ o8. 
Crack, Peter. "Westminster Abbey's Quattrocento Altarpieces: Three Ornaments and Their 'Worship' in the Twentieth Century." 263-295.

Daly, Dennis. Review of Toward by Moira Linehan. 535-538.

Daily, Katie. "Goodness, Exceptionalism, and Sense: Theological Layering in Contemporary American Literature." 665-68o.

de Hamel, Christopher. The Book in the Cathedral: The Last Relic of Thomas Becket (reviewed). See Charoenkitsuksun, Review of The Book in the Cathedral.

de Paepe, Harry and Jan van der Veken. The Mystic Lamb: Admired and Stolen (reviewed). See Charoenkitsuksun, Review of The Mystic Lamb.

del Toro García, Leticia. Review of Finding the World's Fullness: On Poetry, Metaphor and Mystery by Robert Cording. 525-527.

DeCock, Miriam. Review of Exegeting the Jews: The Early Reception of the Johannine 'Jews' by Michael G. Azar. 197-198.

DeCoste, D. Marcel. “'When You Stop Pretending that you Know': Gnosis, Humility, and Christian Charity in Cormac McCarthy's The Stonemason." $125^{-146 .}$

Dill, Scott A. A Theology of Sense:John Updike Embodiment, and Late TwentiethCentury American Literature (reviewed). See Daily, "Goodness, Exceptionalism, and Sense."

Douglass, Rachel. "The Eschatological Key: A Musical Approach to Christian Hope." $455^{-469 .}$

Evans, Helen C., ed. Armenia: Art, Religion and Trade in the Middle Ages. See Aghajanian, Review of Armenia.

Fromont, Cécile, ed. Afro-Catholic Festivals in the Americas: Performance, Representation, and the Making of Black Atlantic Tradition (reviewed). See CottiLowell, "Entering the Latin American Igbodu."

Gade, Anna M. Muslim Environmentalisms: Religious and Social Foundations (reviewed). See Malick, Review of Muslim Environmentalisms.

Garrard, Mary D. Artemisia Gentileschi and Feminism in Early Modern Europe (reviewed). See Coonradt, Review of Artemisia Gentileschi and Feminism.

Gibson, Richard Hughes and James Edward Beitler III. "Companions in the Study." 471-484.

Goodwin, Megan. Abusing Religion: Literary Persecution, Sex Scandals, and American Minority Religions (reviewed). See Khan, Review of Abusing Religion.

Graff, Thomas. Review of The Judgment of Love: An Investigation of Salvific Judgment in Christian Eschatology by James M. Matarazzo Jr. 689-692.

Hankins, Luke. Radiant Obstacles (reviewed). See Southward, "Redeeming Poetry." 
Hitt, Mary Anna and Anna Jane Joyner, hosts. "Seasonz: Bring the Light" of the No Place like Home Podcast (reviewed). See Murphy "Christianity and Climate Change."

Hoffman, Tiffany. Review of Leonardo's Paradox: Word and Image in the Making of Renaissance Culture by Joost Keizer. 681-684.

Hrdlicka, Steven. “'But Such a Mind, Mak'st God Thy Guest': Catholic Theology and Prudence in Ben Johnson's Eupheme and Anthony van Dyck's Portrait of Venetia Digby." $565-589$.

Keizer, Joost. Leonardo's Paradox: Word and Image in the Making of Renaissance Culture (reviewed). See Hoffman, Review of Leonardo's Paradox.

Khan, M. Anjum. Review of Abusing Religion:Literary Persecution, Sex Scandals, and American Minority Religions by Megan Goodwin. 349-351.

Kingsley-Smith, Jane. The Afterlife of Shakespeare's Sonnets (reviewed). See Kitzes, "And Now They Range."

Kitzes, Adam H. “'And Now They Range': Early Modern Poems and Their Survival." 187-196.

Klug, Nate. Hosts and Guests (reviewed). See Southward, "Redeeming Poetry."

Knight, Mark. Good Words: Evangelicalism and the Victorian Novel (reviewed). See Stutz, Review of Good Words.

Kolin, Philip C. Reaching Forever: Poems (reviewed). See Linehan, Reaching Forever.

Lee, Andrew William. Review of Eros Ideologies: Writings on Art Spirituality, and the Decolonial by Laura E. Pérez. 212-214.

Linehan, Moira. Review of Reaching Forever: Poems by Philip C. Kolin. 202204.

Linehan, Moira. Toward (reviewed). See Daly, Review of Toward.

Loia, Donato. "Diverse Paths to the Study of Religion and Spirituality." 509-523.

Luhrmann, T.M. How God Becomes Real: Kindling the Presence of Invisible Others (reviewed). See Mileski, Review of How God Becomes Real.

Maddox IV, John T. Challenging the Black Atlantic: The New World Novels of Zapata Olivella and Gonçalves (reviewed). See Cotti-Lowell, "Entering the Latin American Igbodu."

Martin, Paul C. "The Picture of Language in Seeing the Nature of God in Kabbalah and Tantra" $5-34$.

Malick, Ibrahim Sajid. Review of Muslim Environmentalisms: Religious and Social Foundations by Anna M. Gade. 341-343.

Marshall, Nate. Finna (reviewed). See Southward, "Redeeming Poetry."

Matarazzo Jr., James M. The Judgment of Love: An Investigation of Salvific Judgment in Christian Eschatology (reviewed). See Graff, Review of The Judgment of Love. 
Maza, Edward. "Rewriting Genesis: Biblical Reception and the Case of Barnett Newman." 296-310.

Mileski, Greg. Review of How God Becomes Real: Kindling the Presence of Invisible Others by T.M. Luhrmann. 205-211.

Murphy, Peter. The Long Life of a Short Private Poem:Reading and Remembering Thomas Wyatt. See Kitzes, "And Now They Range."

Murphy, Robinson. "Christianity and Climate Change." 311-326.

Murray, Caleb. "Allen Ginsberg's Jeremiad: Queer Utopia, Religious Mythology, and the Undoing of Modernism." 590-616.

Najarian, James. "Introduction: 25 Years of Religion and the Arts." 1-4.

Oleas-Mogollón, Isabel. "Humility and Influence: Female Agency and the Confraternity of Saint Rosalia in Eighteenth-Century Cuenca." 35-69.

Pérez, Laura E. Eros Ideologies: Writings on Art, Spirituality, and the Decolonial (reviewed). See Lee, Review of Eros Ideologies.

Russell, Jesse. "Jewish Humanism in the Late Work of Geoffrey Hill." 99-124.

Salzman, Paul. Editors Construct the Renaissance Canon, 1825-1915 (reviewed). See Kitzes, "And Now They Range."

Schor, Laura S. Sophie Halaby in Jerusalem: An Artist's Life. See Scott, Review of Sophie Halaby in Jerusalem.

Scott, Braden Lee. Review of Sophie Halaby inJerusalem: An Artist's Life by Laura S. Schor. 539-542.

Schade, Leah D. and Margaret Bullitt-Jonas, eds. Rooted and Rising: Voices of Courage in a Time of Climate Crisis (reviewed). See Murphy "Christianity and Climate Change."

Shalit-Kollender, Michal. “The Fresco Cycle of Saint Maria Maddalena De' Pazzi (1566-16o7)." 421-454.

Snow, Andrea C. Review of Dissimilar Similitudes: Devotional Objects in Late Medieval Europe by Caroline Walker Bynum. 199-201.

Southward, David. "Redeeming Poetry." 327-336.

Stacy, Ivan. "Masked Violence: The Carnivalesque in Contemporary Bhutanese Film." 641-664.

Strongman, Roberto. Queering Black Atlantic Religions: Transcorporeality in Candomblé, Santería, and Vodou (reviewed). See Cotti-Lowell, "Entering the Latin American Igbodu."

Stutz, Chad P. Review of Good Words: Evangelicalism and the Victorian Novel by Mark Knight. 685-688.

Teipen, Alfons H. Review of In-Between Identities: Signs of Islam in Contemporary American Writing by John C. Waldmeir. 543-544.

Tobin, Daniel. On Serious Earth: Poetry and Transcendence (reviewed). See Southward, "Redeeming Poetry." 
Tóth, Sára. “'We are not Aliens in the Universe': Marilynne Robinson's Imaginative Re-enchantment of Protestantism." 147-172.

Veldman, Robin Globus. The Gospel of Climate Skepticism: Why Evangelical Christians Oppose Action on Climate Change (reviewed). See Murphy, "Christianity and Climate Change."

Waldmeir, John C. In-Between Identities: Signs of Islam in Contemporary American Writing (reviewed). See Teipen, Review of In-Between Identities.

Woodward, Tanya Jo. Review of Seasoned Speech: Rhetoric in the Life of the Church by James E. Beitler, III. 337-340. 